\title{
Caryospora peneireiroi n. sp. (Apicomplexa: Eimeriidae) in the common kestrel, Falco tinnunculus (Falconiformes: Falconidae), in mainland Portugal
}

Caryospora peneireiroi n. sp. (Apicomplexa: Eimeriidae) no peneireiro, Falco tinnunculus (Falconiformes: Falconidae), em Portugal Continental

\author{
Sergian Vianna Cardozo ${ }^{1,2}$; Bruno Pereira Berto ${ }^{3 *}$; Inês Caetano ${ }^{4}$; Viviane Camara Maniero ${ }^{1}$; \\ Isabel Pereira da Fonseca ${ }^{5}$; Carlos Wilson Gomes Lopes ${ }^{6}$
}

\begin{abstract}
${ }^{1}$ Programa de Pós-graduaçăo em Biomedicina Translacional, Universidade do Grande Rio - UNIGRANRIO, Duque de Caxias, RJ, Brasil

${ }^{2}$ Programa de Pós-graduação em Ciência, Tecnologia e Inovação em Agropecuária, Universidade Federal Rural do Rio de Janeiro - UFRRJ, Seropédica, RJ, Brasil

${ }^{3}$ Departamento de Biologia Animal, Instituto de Ciências Biológicas e da Saúde, Universidade Federal Rural do Rio de Janeiro - UFRRJ, Seropédica, RJ, Brasil

${ }^{4}$ Centro de Recuperação de Animais Silvestres de Lisboa, Parque Florestal de Monsanto, Lisboa, Portugal

${ }_{5}^{5}$ Centro Interdisciplinar de Investigação em Sanidade Animal, Faculdade de Medicina Veterinária, Universidade de Lisboa, Lisboa, Portugal

${ }^{6}$ Departamento de Parasitologia Animal, Instituto de Veterinária, Universidade Federal Rural do Rio de Janeiro - UFRRJ,

Seropédica, RJ, Brasil
\end{abstract}

Received March 7, 2016

Accepted April 7, 2016

\begin{abstract}
The common kestrel Falco tinnunculus Linnaeus, 1758, is a widespread raptor, native in Europe, Asia and Africa, and vagrant in the Americas. In the current work, 27 fecal samples were collected from common kestrels kept in the Lisbon Center for Wild Animal Recovery, located at Monsanto Forest Park, Lisbon, Portugal. Five (19\%) of them were found to be passing an undescribed species of Caryospora in their feces. The oocysts of Caryospora peneireiroi $\mathrm{n}$. sp. were ellipsoidal with a bilayered wall and measured $47.1 \times 37.6 \mu \mathrm{m}$ with a shape index of 1.25 . No micropyle, oocyst residuum or polar granule was present. The sporocysts were subspherical, measuring $25.1 \times 24.3 \mu \mathrm{m}$. Stieda, sub-Stieda and para-Stieda bodies were absent. The sporocyst residuum was composed of many homogenous globules scattered throughout the periphery of the sporocyst. This is the fourth caryosporan species reported from F. tinnunculus.
\end{abstract}

Keywords: Coccidia, oocysts, morphology, taxonomy, conservation, raptors.

\section{Resumo}

O peneireiro Falco tinnunculus Linnaeus, 1758, é uma ave de rapina com vasta distribuição geográfica, nativa da Europa, Ásia e África, e errante nas Américas. No presente trabalho, 27 amostras de fezes foram coletadas de peneireiros mantidos no Centro de Recuperação de Animais Silvestres de Lisboa, localizado no Parque Florestal de Monsanto, Lisboa, Portugal. Cinco (19\%) deles eliminaram uma espécie não descrita de Caryospora em suas fezes. Os oocistos de Caryospora peneireiroi $\mathrm{n}$. sp. foram elipsoides, com parede de dupla camada, medindo $47,1 \times 37,6 \mu \mathrm{m}$, e índice morfométrico de 1,25. A micrópila, resíduo do oocisto e grânulo polar não foram evidenciados. Os esporocistos foram subesféricos, medindo $25,1 \times 24,3 \mu \mathrm{m}$. Corpos de Stieda, substieda e parastieda não se manifestaram. Resíduo do esporocisto foi composto de muitos glóbulos homogêneos espalhados por toda a periferia do esporocisto. Essa é a quarta espécie Caryospora descrita de F. tinnunculus.

Palavras-chave: Coccidia, oocistos, morfologia, taxonomia, conservação, aves de rapina.

*Corresponding author: Bruno Pereira Berto. Departamento de Biologia Animal, Instituto de Ciências Biológicas e da Saúde, Universidade Federal Rural do Rio de Janeiro - UFRRJ, Rodovia BR-465 Km 7, CEP 23897-000,

Seropédica, RJ, Brasil. e-mail: bertobp@ufrrj.br 


\section{Introduction}

The common kestrel Falco tinnunculus Linnaeus, 1758, is a raptor observed in several environments, easily recognizable through its ability to hover while searching for its prey. In Portugal, this species was one of the most abundant in the 1940s; however, it suffered a sharp decline over the subsequent decades. Nowadays, although the population trend appears to be still decreasing, it is recognized that the population size is still extremely large (PALMA, 1985; Birdlife International, 2015).

Genus Caryospora Leger, 1904, is occasionally reported in raptors and reptiles, which act as its definitive hosts, and in rodents, which act as its intermediate hosts (UPTON et al., 1990; BERTO et al., 2014). Caryospora is the third largest genus in the family Eimeriidae. Caryospora spp. have now been reported worldwide, especially in raptors kept in captivity (UPTON et al., 1992; PAPAZAHARIADOU et al., 2001; MCALLISTER et al., 2013a, b). However, little is known about the distribution and importance of species of the genus Caryospora in free-living birds (YANG et al., 2014). The current work describes a new species of Caryospora from the common kestrels F. tinnunculus that were being kept for rehabilitation and reintroduction into the wild at the Lisbon Center for Wild Animal Recovery (Centro de Recuperação de Animais Silvestres de Lisboa, LxCRAS), Monsanto Forest Park, Lisbon, Portugal.

\section{Materials and Methods}

Twenty-seven fecal samples were collected from common kestrels that were being kept in individual cages on the premises of the Lisbon Center for Wild Animal Recovery (LxCRAS), located in Monsanto Forest Park, Lisbon, Portugal. The samples were collected immediately after defecation and were placed in plastic vials containing $2.5 \%$ potassium dichromate $\left(\mathrm{K}_{2} \mathrm{Cr}_{2} \mathrm{O}_{7}\right)$ solution at 1:6 (v/v). In the laboratory, the samples were incubated at room temperature for 10 days or until day three when around $70 \%$ of the oocysts had sporulated. The oocysts were recovered by means of flotation in Sheather's sugar solution (specific gravity: 1.20). Morphological observations, line drawings, photomicrographs and measurements were made using an Olympus BX40 microscope equipped with a digital camera (Olympus DP10). The line drawings were edited using two software applications from CorelDRAW ${ }^{\circledR}$ (Corel Draw Graphics Suite, Version 11.0, Corel Corporation, Canada), specifically Corel DRAW and Corel PHOTO-PAINT. All measurements were made in micrometers and are given as the range followed by the mean in parentheses. The descriptions of oocysts and sporocysts followed the guidelines of Duszynski \& Wilber (1997) and Berto et al. (2014), as follows: oocyst (O) length (L) and width $(\mathrm{W})$ and their ranges and ratios (L/W); micropyle $(\mathrm{M})$, oocyst residuum (OR), polar granule (PG) and sporocyst (SP) length (L) and width (W) and their ranges and ratios (L/W); and Stieda body (SB), sub-Stieda body (SSB), para-Stieda body (PSB), sporocyst residuum (SR), sporozoite (SZ), refractile body (RB) and nucleus $(\mathrm{N})$.

\section{Results}

\section{Caryospora peneireiroi n. sp.}

(Figures 1a, b)

Description of sporulated oocyst: Oocyst shape: ellipsoidal; oocyst wall: bilayered, -2.0 thick; outer layer smooth; $\mathrm{L} \times \mathrm{W}$ $(\mathrm{n}=20) 47.1 \times 37.6(42-49 \times 34-40)$; L/W 1.25 (1.2-1.4). M, OR, PG: all absent. Distinctive features of oocysts: large oocyst ellipsoidal lacking $\mathrm{M}, \mathrm{OR}$, and PG.
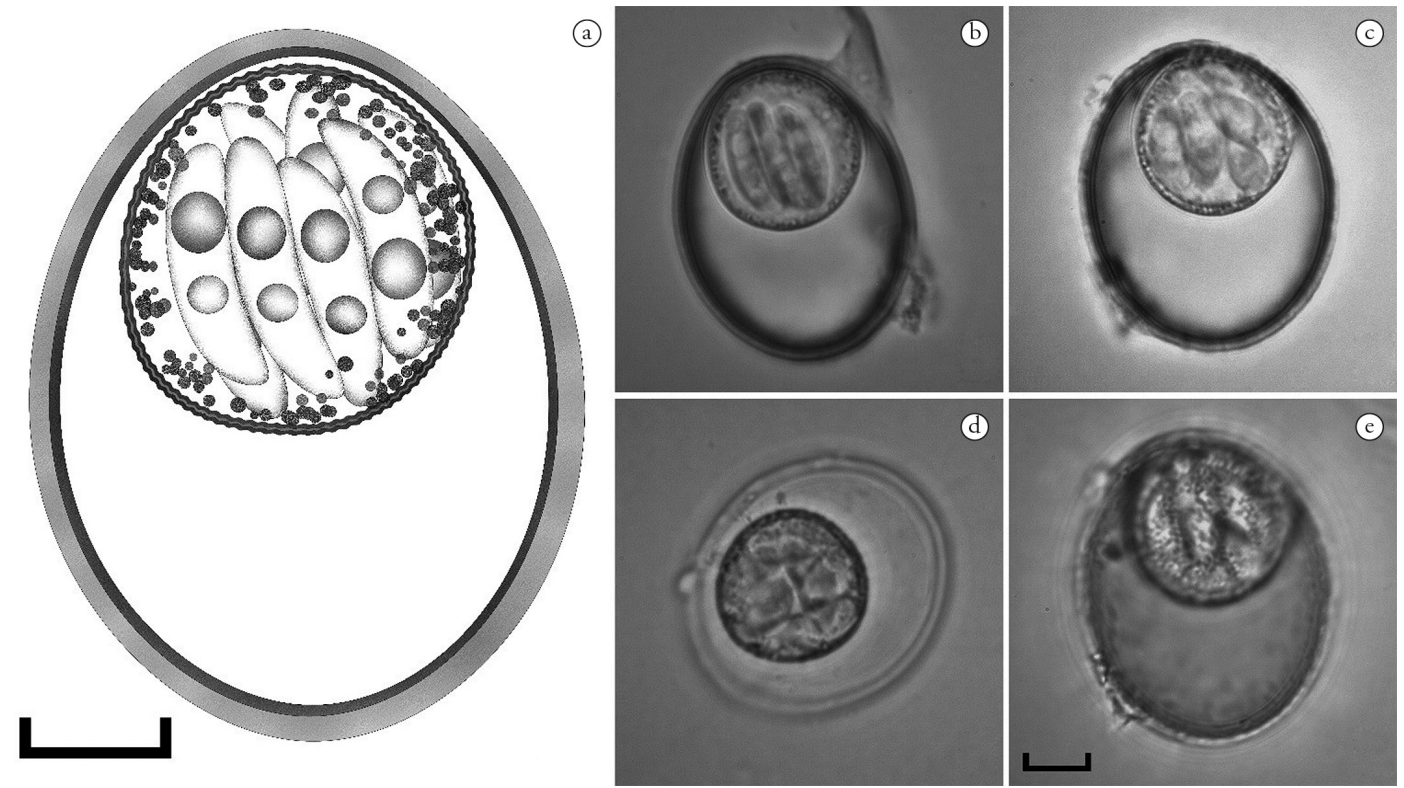

Figure 1. Oocysts of Caryospora peneireiroi, a new coccidium species recovered from the common kestrel Falco tinnunculus. (a) Composite line drawing; (b-e) Photomicrographs. Bars $=10 \mu \mathrm{m}$. 
Description of sporocyst and sporozoites: Sporocyst shape: subspherical; sporocyst wall: single-layered, $\sim 0.8$ thick, slightly rough to wrinkled; $\mathrm{L} \times \mathrm{W}(\mathrm{n}=20) 25.1 \times 24.3(24-27 \times 24-25)$; L/W 1.03 (1.0-1.1); SB, SSB, PSB: all absent; SR: present; SR characteristics: composed of many homogenous globules scattered throughout the periphery of the SP. SZ: stout, L $\times W$ $(\mathrm{n}=5) 17.0 \times 4.2(15-18 \times 3-5)$ in situ, arranged parallel to one another in SP. Each SZ without striations discernible, but with one medium-sized spherical PRB, 3.0 (2-4) wide; single $\mathrm{N}$ in midpoint of body. Distinctive features of sporocyst: large size, presence of globules scattered throughout the periphery of the SP, and large SZ.

\section{Taxonomic summary}

Type host: common kestrel Falco tinnunculus Linnaeus, 1758 (Aves: Falconiformes: Falconidae).

Other hosts: None.

Type specimens: Phototypes and line drawings are deposited and available (http://r1.ufrri.br/lcc) in the Parasitology Collection of the Coccidia and Coccidiosis Laboratory, at the Federal Rural University of Rio de Janeiro (UFRRJ), located in Seropédica, State of Rio de Janeiro, Brazil. Photographs of the type-host specimens (symbiotypes) are deposited in the same collection. The repository number is $\mathrm{P}-63 / 2015$.

Type locality: Lisbon Center for Wild Animal Recovery (LxCRAS), Lisbon, Portugal (384 '22.9” N, 9¹1’02.3” W).

Prevalence: Five out of 27 (19\%).

Sporulation: Exogenous. All oocysts were passed in the feces unsporulated and were fully sporulated by day 7 in $\mathrm{K}_{2} \mathrm{Cr}_{2} \mathrm{O}_{7}$ solution at room temperature.

Prepatent and patent periods: Unknown.

Site of infection, definitive host: Unknown. Oocysts recovered from feces.

Site of infection, secondary host: Unknown.

Endogenous stages, definitive host: Unknown.

Endogenous stages, secondary host: Unknown.

Cross-transmission: None to date.
Pathology, definitive host: Unknown.

Pathology, secondary host: Unknown.

Etymology: The specific epitaph is derived from the common local name for the host, which is 'peneireiro'.

\section{Remarks}

Table 1 and Table 2 show some characteristic features of Caryospora spp. described from Accipitriformes and Falconiformes respectively. Of Caryospora species listed in Table 1, only Caryospora aquilae Volf, Koudela and Modrý, 2000, Caryospora petersoni McAllister, Duszynski and McKown, 2013, and Caryospora hanebrinki McAllister, Duszynski and McKown, 2013, have oocyst measurements similar to those of $C$. peneireiroi. However, C. aquilae can be distinguished through the smooth surface of the SP and smaller SZ, which has N not discernible. Caryospora petersoni and C. hanebrinki, in turn, can easily be distinguished through the smooth surface of the SP, SR forming a compact mass and SZ with striations. Of the species of Caryospora described from Falconiformes (Table 2), only Caryospora megafalconis Klüh, 1994, and Caryospora biarmicusis Alyousif, Alfaleh and Al-Shawa, 2011, have oocyst measurements similar to those of $C$. peneireiroi. However, C. megafalconis can be distinguished through the smooth surface of the SP and SR forming a compact mass. Caryospora biarmicusis can be distinguished through the presence of OR and smaller SP with smooth surface.

\section{Discussion}

The family Falconidae comprises 66 species of raptors distributed in 11 genera. The genus Falco comprises 39 species worldwide, while other genera are exclusively Neotropical (Birdlife International, 2015). The common kestrel F. tinnunculus Linnaeus, 1758, is a widespread kestrel species, found throughout Europe, Asia and Africa. In Europe, F. tinnunculus is migratory in winter, heading for southern Europe and sub-Saharan Africa (VILLAGE, 1990; Birdlife International, 2015).

Table 1. Comparative data of Caryospora spp. described from Accipitridae (Accipitriformes).

\begin{tabular}{|c|c|c|c|c|c|c|c|}
\hline \multirow{2}{*}{ Species } & \multirow{2}{*}{ Host } & \multirow{2}{*}{ Locality } & \multirow{2}{*}{ Reference } & \multicolumn{2}{|c|}{ Oocyst } & \multicolumn{2}{|c|}{ Sporocyst } \\
\hline & & & & Shape & Size $(\mu \mathrm{m})$ & Shape & Size $(\mu \mathrm{m})$ \\
\hline C. arcayae & $\begin{array}{l}\text { Buteo magnirostris; } \\
\text { Buteo platypterus }\end{array}$ & Venezuela; USA & Upton et al. (1990) & subspherical & $32.9 \times 29.4$ & subspherical & $21.9 \times 21.8$ \\
\hline C. uptoni & Buteo jamaicensis & USA & $\begin{array}{c}\text { Lindsay \& } \\
\text { Blagburn }(1986,1989)\end{array}$ & subspherical & $28.1 \times 26.4$ & subspherical & $18.2 \times 17.9$ \\
\hline C. kansasensis & Buteo swainsoni & USA & Upton et al. (1990) & ovoid & $37.2 \times 32.6$ & spherical & 22.5 \\
\hline C. lindsayi & B. jamaicensis & USA & Upton et al. (1990) & subspherical & $33.7 \times 31.6$ & subspherical & $19.2-22.0$ \\
\hline C. aquilae & Aquila chrysaetos & Czech Republic & Volf et al. (2000) & $\begin{array}{l}\text { subspherical to } \\
\text { ellipsoidal }\end{array}$ & $43.0 \times 37.5$ & subspherical & $23.8 \times 23.3$ \\
\hline C. circi & Circus aeruginosus & Czech Republic & Volf et al. (2000) & ovoid & $24.5 \times 21.8$ & subspherical & $16.2 \times 15.6$ \\
\hline C. hanebrinki & $\begin{array}{l}\text { Haliaeetus } \\
\text { leucocephalus }\end{array}$ & USA & McAllister et al. (2013a) & $\begin{array}{l}\text { ellipsoidal to } \\
\text { ovoidal }\end{array}$ & $48.1 \times 42.1$ & spherical & 24.8 \\
\hline C. petersoni & Accipiter striatus & USA & McAllister et al. (2013b) & subspherical & $43.1 \times 39.8$ & $\begin{array}{l}\text { subspherical to } \\
\text { spherical }\end{array}$ & $23.4 \times 23.3$ \\
\hline
\end{tabular}


Table 2. Comparative data of Caryospora spp. described from Falconidae (Falconiformes).

\begin{tabular}{|c|c|c|c|c|c|c|c|}
\hline \multirow{2}{*}{ Species } & \multirow{2}{*}{ Host } & \multirow{2}{*}{ Locality } & \multirow{2}{*}{ Reference } & \multicolumn{2}{|c|}{ Oocyst } & \multicolumn{2}{|c|}{ Sporocyst } \\
\hline & & & & Shape & Size $(\mu \mathrm{m})$ & Shape & Size $(\mu \mathrm{m})$ \\
\hline C. falconis & $\begin{array}{l}\text { Falco peregrinus; } \\
\text { Falco subbuteo; } \\
\text { Falco tinnunculus }\end{array}$ & Europe & $\begin{array}{l}\text { Upton et al. (1990); } \\
\text { Alfaleh et al. (2013) }\end{array}$ & subspherical & $29.5 \times 36.5$ & subspherical & $21.0 \times 23.0$ \\
\hline C. kutzeri & $\begin{array}{c}\text { Falco biarmicus; } \\
\text { Falco cherrug, Falco } \\
\text { jugger; Falco mexicanus }\end{array}$ & Europe & $\begin{array}{l}\text { Upton et al. (1990); } \\
\text { Alfaleh et al. (2013) }\end{array}$ & subspherical & $38.7 \times 34.1$ & ovoid & $24.6 \times 21.0$ \\
\hline C. neofalconis & $\begin{array}{c}\text { F. biarmicus; F } \\
\text { mexicanus; Fsubbuteo; } \\
\text { F. tinnunculus; F. peregrinus }\end{array}$ & $\begin{array}{l}\text { Europe; } \\
\text { Mexico }\end{array}$ & $\begin{array}{l}\text { Upton et al. (1990); } \\
\text { Alfaleh et al. } \\
\text { (2013); Santana- } \\
\text { Sánchez et al. } \\
\text { (2015) }\end{array}$ & subspherical & $27.0 \times 23.8$ & ovoid & $18.8 \times 14.8$ \\
\hline C. boeri & F. tinnunculus & Europe & Alfaleh et al. (2013) & subspherical & $36.6 \times 33.4$ & ovoid & $27.8 \times 19.6$ \\
\hline C. megafalconis & $\begin{array}{l}\text { F. biarmicus; F. mexicanus; } \\
\text { F. peregrinus; F. subbuteo }\end{array}$ & Europe & Alfaleh et al. (2013) & $\begin{array}{l}\text { subspherical } \\
\text { or ovoid }\end{array}$ & $43.6 \times 35.8$ & spherical & 23.8 \\
\hline C. biarmicusis & F. biarmicus & Saudi Arabia & $\begin{array}{l}\text { Alyousif et al. } \\
\qquad(2011) ; \\
\text { Alfaleh et al. (2013) }\end{array}$ & ovoid & $40.2 \times 34.7$ & spherical & 20.1 \\
\hline C. cherrughi & F. cherrug & Saudi Arabia & Alfaleh et al. (2013) & ovoid & $32.1 \times 29.3$ & ellipsoidal & $24.1 \times 19.6$ \\
\hline C. peneireiroi & F. tinnunculus & Portugal & current work & ellipsoidal & $47.1 \times 37.6$ & subspherical & $25.1 \times 24.3$ \\
\hline
\end{tabular}

These geographical ranges and the reports of Caryospora spp. from F. tinnunculus and other Falco spp. emphasize the potential transmission and dispersion of these coccidians in Europe, Asia and Africa. Moreover, this coccidian dispersion may be worldwide if we consider that some specimens of $F$. tinnunculus are vagrant in the Americas and that some Falco spp. are native in both the New and the Old World, for example: Falco columbarius Linnaeus, 1758, Falco peregrinus Tunstall, 1771, and Falco rusticolus Linnaeus, 1758. This assumption of coccidian dispersion across species of Falco and subsequently of Falconidae is grounded in the concept of intra-familial specificity, which was suggested by Duszynski \& Wilber (1997) and has been reaffirmed in several subsequent studies on coccidians in birds (BERTO et al., 2011).

In this regard, the species described in the current study was primarily compared with the Caryospora spp. described from Falconidae, which is the single family of Falconiformes. However, since falconids are close to accipitrids, and because earlier studies on Caryospora spp. in raptors compared coccidians through descriptions from these two families (UPTON et al., 1986, 1990), C. peneireiroi was also compared in the current work with Caryospora spp. described from Accipitridae.

Therefore, based on the morphological features described above, $C$. peneireiroi is considered to be new to science and to be the fourth caryosporan species reported from $F$. tinnunculus.

\section{Acknowledgements}

We thank the staff at the LxCRAS facility at Monsanto Forest Park, Lisbon, Portugal, who enabled the collection of samples from birds held for rehabilitation and reintroduction into the wild. This study was supported by grants from the Fundação Carlos Chagas Filho de Amparo à Pesquisa do Estado do Rio de Janeiro (FAPERJ), Conselho Nacional de Desenvolvimento Científico e
Tecnológico (CNPq), Fundação Nacional de Desenvolvimento do Ensino Superior Particular (FUNADESP) and Ibero-American Scholarship Programme for Teachers and Researchers Santander Universities.

\section{References}

Alfaleh FA, Alyousif MS, Al-Shawa YR, Al-Quraishy S. Caryospora cherrughisp. n. (Apicomplexa: Eimeriidae) infecting Falco cherrug in Saudi Arabia. Parasitol Res 2013; 112(3): 971-974. http://dx.doi.org/10.1007/ s00436-012-3217-y. PMid:23224640.

Alyousif MS, Alfaleh FA, Al-Shawa YR. Caryospora biarmicusis sp. n. (Apicomplexa: Eimeriidae) infecting falcons from the genus Falco in Saudi Arabia. J Egypt Soc Parasitol 2011; 41(1): 1-6. PMid:21634236.

Berto BP, Flausino W, McIntosh D, Teixeira-Filho WL, Lopes CWG. Coccidia of New World passerine birds (Aves: Passeriformes): a review of Eimeria Schneider, 1875 and Isospora Schneider, 1881 (Apicomplexa: Eimeriidae). Syst Parasitol 2011; 80(3): 159-204. http://dx.doi.org/10.1007/ s11230-011-9317-8. PMid:22002022.

Berto BP, McIntosh D, Lopes CWG. Studies on coccidian oocysts (Apicomplexa: Eucoccidiorida). Rev Bras Parasitol Vet 2014; 23(1): 1-15. http://dx.doi.org/10.1590/S1984-29612014001. PMid:24728354.

Birdlife International. [online]. 2015 [cited 2016 Jan 30]. Available from: http://www.birdlife.org

Duszynski DW, Wilber P. A guideline for the preparation of species descriptions in the Eimeriidae. J Parasitol 1997; 83(2): 333-336. http:// dx.doi.org/10.2307/3284470. PMid:9105325.

Lindsay DS, Blagburn BL. Caryospora uptoni and Frenkelia sp. -like coccidial infections in red-tailed hawks (Buteo borealis). J Wildl Dis 1989; 25(3): 407-409. http://dx.doi.org/10.7589/0090-3558-25.3.407. PMid:2503626. 
Lindsay DS, Blagburn BL. Caryospora uptoni n. sp. (Apicomplexa: Eimeriidae) from red-tailed hawks (Buteo jamaicensis borealis).J Parasitol 1986; 72(5): 762-765. http://dx.doi.org/10.2307/3281470. PMid:3806324.

McAllister CT, Duszynski DW, McKown RD. A new species of Caryospora (Apicomplexa: Eimeriidae) from the bald eagle, Haliaeetus leucocephalus (Accipitriformes: Accipitridae), from Kansas. J Parasitol 2013a; 99(2): 287-289. http://dx.doi.org/10.1645/GE-3236.1. PMid:22992168.

McAllister CT, Duszynski DW, McKown RD. A new species of Caryospora (Apicomplexa: Eimeriidae) from the sharp-shinned hawk, Accipiter striatus (Aves: Accipitriformes). J Parasitol 2013b; 99(3): 490-492. http://dx.doi. org/10.1645/GE-3228.1. PMid:23098064.

Palma L. The present situation of birds of prey in Portugal. In: Newton I, Chancellor RD. Conservation studies on raptors. Cambridge: Technical Publication; 1985. p. 3-14.

Papazahariadou MG, Georgiades GK, Komnenou AT, Ganoti M. Caryospora species in a snowy owl (Nyctea scandiaca). Vet Rec 2001; 148(2): 54-55. http://dx.doi.org/10.1136/vr.148.2.54. PMid:11202556.

Santana-Sánchez G, Flores-Valle IT, González-Gómez M, Vega-Sánchez V, Salgado-Miranda C, Soriano-Vargas E. Caryospora neofalconis and other enteroparasites in raptors from Mexico. Int J Parasitol Parasites Wildl
2015; 4(3): 351-355. http://dx.doi.org/10.1016/j.ijppaw.2015.08.004 PMid:26543806.

Upton SJ, Campbell TW, Weigel M, McKown RD. The Eimeriidae (Apicomplexa) of raptors: Review of the literature and description of new species of the genera Caryospora and Eimeria. Can J Zool 1990; 68(6): 1256-1265. http://dx.doi.org/10.1139/z90-187.

Upton SJ, Current WL, Barnard SM. A review of the genus Caryospora Léger, 1904 (Apicomplexa: Eimeriidae). Syst Parasitol 1986; 8(1): 3-21. http://dx.doi.org/10.1007/BF00010305.

Upton SJ, Odell DK, Walsh MT. Description of the oocysts of Caryospora undata (Apicomplexa) from tufted puffins, Lunda cirrhata (Charadriiformes). Tex J Sci 1992; 44(1): 79-82.

Village A. The Kestrel. London: T. \&. A.D. Poyser; 1990.

Volf J, Koudela B, Modrý D. Two new species of Caryospora Léger, 1904 (Apicomplexa, Eimeriidae) from accipitrid raptors. Syst Parasitol 2000; 46(1): 23-27. http://dx.doi.org/10.1023/A:1006227911679. PMid:10803432.

Yang R, Brice B, Ryan U. A new Caryospora coccidian species (Apicomplexa: Eimeriidae) from the laughing kookaburra (Dacelo novaeguineae). Exp Parasitol 2014; 145: 68-73. http://dx.doi.org/10.1016/j.exppara.2014.07.008. PMid:25092438. 